\title{
Investigation and Control of Tomato Production Plant
}

\author{
S. A. Hussein'1, D. M. Alsekait ${ }^{1}$, G. A. Gasmelsead ${ }^{2}$ \\ ${ }^{1}$ Princess Nourah Bint Abdulrahman University, Riyadh, KSA \\ ${ }^{2}$ Teganaa University, Sudan, Khartoum \\ Email: sahussein@pnu.edu.sa,DMAlSekait@pnu.edu.sa,gurashigasm@gmail.com
}

How to cite this paper: Hussein, S.A., Alsekait, D.M. and Gasmelsead, G.A. (2020) Investigation and Control of Tomato Production Plant. Food and Nutrition Sciences, $11,1-7$.

https://doi.org/10.4236/fns.2020.111001

Received: September 27, 2019

Accepted: January 3, 2020

Published: January 6, 2020

Copyright ( 2020 by author(s) and Scientific Research Publishing Inc. This work is licensed under the Creative Commons Attribution International License (CC BY 4.0).

http://creativecommons.org/licenses/by/4.0/

\begin{abstract}
The demand for tomato paste is daily used over the year with the fact that it is abundant in certain seasons and scarce during other season. Many methods are used to preserve the juice or the paste through drying and with addition of preservative. Tomato grows under ambient conditions or in green houses at a temperature of $20^{\circ} \mathrm{C}-27^{\circ} \mathrm{C}$ with high contents of vitamins $\mathrm{A}$ and $\mathrm{B}$, potassium, iron, and phosphors. Tomato is a source of fiber; it doesn't contain sodium salt, fats, or cholesterol; in fact it is the cheapest food of the poor common people. Tomato while waiting for processing to paste deteriorates rather quickly, and shall be thoroughly rinsed with sterilized clean water using rotary washers. The washed tomato is inspected, sorted, and chopped. The tomato liquor is processed through an extraction unit where the juice is separated away from outer skin, seeds and fibers. To avoid oxidation and foaming the tomato liquor is deaerated; the juice is deaerated by taking the vacuum as soon as it is formed. A double-effect evaporator is used to concentrate the tomato liquor under partial vacuum of 0.5 atmospheres; this is important to minimize heat damage, oxidation and dark color. The tomato paste is then sterilized with small amount of non-harmful preservatives and then canned, labeled and sent to store. To achieve the international standard specifications and metrology organization a control system is developed, tuned and analyzed for stability conditions. It is recommended that a tomato production plant has to be constructed in countries like Sudan and other countries with similar weather conditions.
\end{abstract}

\section{Keywords}

Tomato Paste, Sterilization, Control, Food Processing Technology, Food Science \& Technology 


\section{Literature Review}

Tomato paste is thick paste made by processing tomatoes to reduce its moisture content, by evaporating in double or triple-effects evaporates [1] [2] [3]. Tomato is valuable raw material for very wide range of foods and always needed by the food industries. Tomato is crushed and concentrated to paste; the simplest method for processing tomato paste consists of washing, sorting, pulping, extraction, mixing with salt, preservatives and the canned [4] [5] [6]. Tomato is considered as a source of vitamin A, B and C, with considerable amount of potassium, iron and phosphorus [7] [8] [9]. The demand for processing tomato to paste is that high seasonal production of tomato happens in short period, difficult to be stored, get rotten and spoiled to waste [10] [11].

Tomato is collected from farms, sorted and washed to remove dirt and resorting again. Washing is an ultimate process that has to be controlled. Tomato crushing is a necessary step after which the seeds and peels are separated [12] [13] [14]. Washing removes molds, insects, drosophila eggs and other contaminants. The efficiency of washing determines the microbial count [15] [16]. As tomato is acidic, it has to be sterilized; tomato-heating process is carried out at temperature of $90^{\circ} \mathrm{C}$ under partial vacuum to minimize heat damage and oxidation [17] [18]. The type of evaporators used must be optimized; single effect has steam economy of less than unity, while double and triple effects have steam economy of greater than 2 [19]. Often the vapors generated in food concentration processes contain various volatile compounds with characteristics of special food flavor; sometime the flavor volatiles are stripped from the vapor and returned to the finished product. A control system has to be designed, with specific control strategy [20] [21]. The control is important to insure the quality satisfying the international standard specifications. The system transfer functions need to be identified tuned and checked for stability analysis. The system is to be simulated and the type of controller has to be nominated in each control loop [22] [23].

\section{Objectives}

1) Investigation of manufacturing tomato paste from improved local varieties.

2) Design and development of a control system to keep the quality of the paste up to international standard specifications.

\section{Methodology}

\section{Experimental procedure}

Fresh tomato was obtained from the market, well-sorted, washed, mixed by a mixing machine and filtered. $0.5 \%$ of common salt and $0.5 \%$ sodium citrate were added while mixing for 10 minutes [24]. The tomato liquor was then introduced in a laboratory scale double-effect evaporator to concentrate the juice to $70 \%$ solid. The thick liquor juice is then further dried to $20 \%$ moisture in a rotary dryer; the paste is then packed in small plastic cans [25]. 
The washing, sorting and mixer equipment are to be selected according to the capacity of the plant. The type of evaporator is double-'effect that will be designed and controlled [26]. The dimensions including the diameter of the calandria, the surface area, the number of tubes and height of the effects are determined. A control strategy is developed, the transfer functions are identified, and using the overall transfer functions the system is simulated and the controller that gives minimum overshot is selected [27].

\section{Design Procedure}

From material and energy balances the major equipments are designed and their dimensions are tabulated [28].

Controllers tuning and stability:

- The transfer functions are specified $\left(G_{c}, G_{v}, G_{p}, G_{m}\right)$.

- The characteristic equations are calculated.

- Routh and Z-N are used to get the adjustable parameters $\left(K_{c}, \tau_{i}, \tau_{D}\right)$.

- The systems are simulated for each loop; the type of controller is selected and installed into the control loop.

\section{Results and Discussion}

\section{Design of double-effect evaporator}

Table 1 summarizes the design of the double-effect evaporator.

The material of construction used for tube and shell is stainless steel. Figure 1 and Figure 2 highlight the evaporator's both backward and forward feeds.

Table 1. Summary of the design.

\begin{tabular}{ccc}
\hline Title & First effect & Second effect \\
\hline Heating surface area, $\mathrm{m}^{2}$ & 39 & 41.0 \\
Length of tube, $\mathrm{m}$ & 5 & 5 \\
Height of effect, m & 7 & 7 \\
Pitch of tube, $\mathrm{m}$ & 0.07 & 62 \\
Number of tubes & 62 & 15 \\
\hline Thickness of tube and shell, $\mathrm{mm}$ & 15 & 6.07 \\
\hline
\end{tabular}

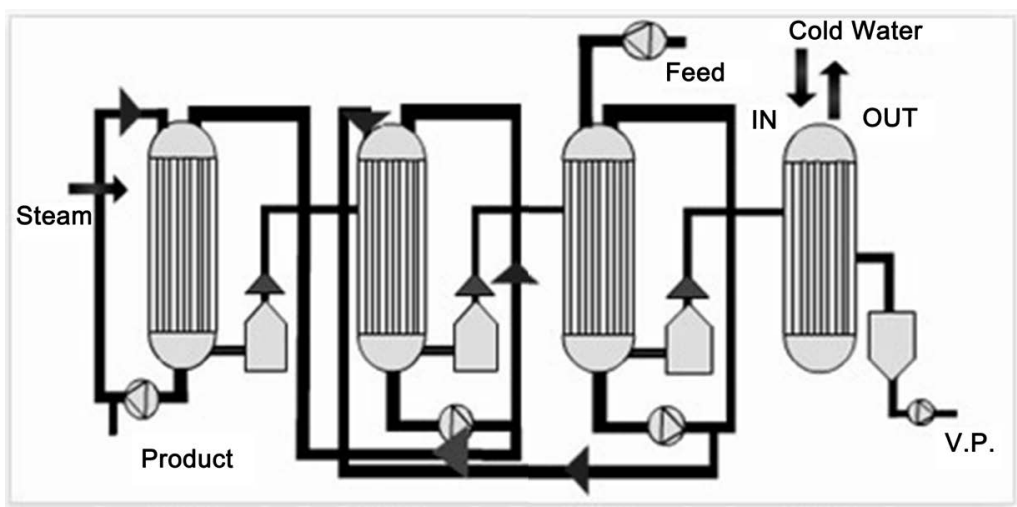

Figure 1. Backward feed for double effect evaporator. 


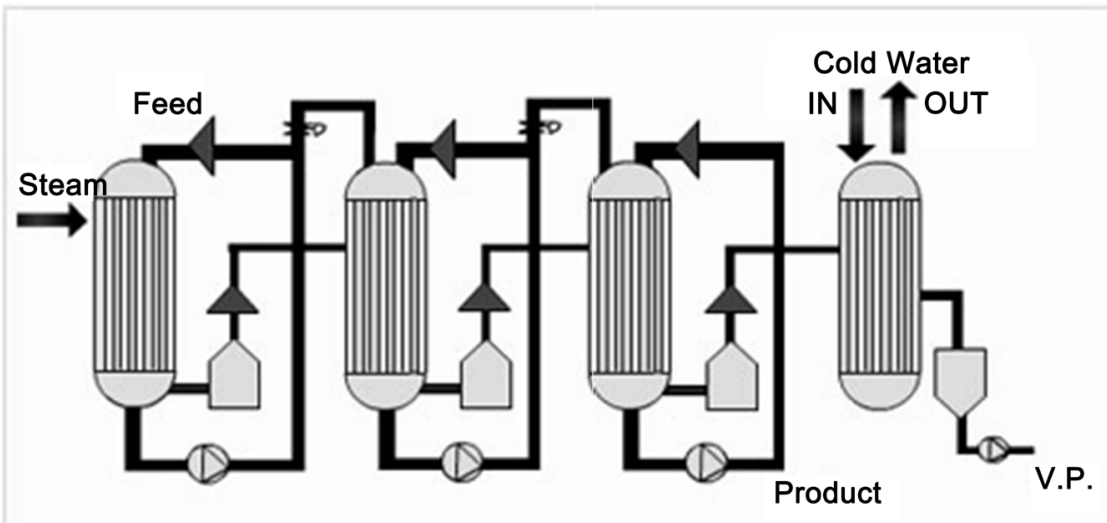

Figure 2. Forward feed for double effect evaporator.

\section{Transfer Functions Identification:}

$$
\begin{gathered}
G_{c}=K_{c} \\
G_{v}=\frac{10}{S+1} \\
G_{P}=\frac{15}{(S+1)(2 S+1)} \\
G_{m}=1 \\
\text { OLTF }=\frac{K_{c}}{100 S^{3}+80 S^{2}+17 S+1}
\end{gathered}
$$

Bode Plot:

MATLAB Format:

num $=[1]$

den $=\left[\begin{array}{llll}100 & 80 & 17 & 1\end{array}\right] ;$

sys $=\operatorname{tf}($ num, den);

Bode (sys); grid.

Figure 3 shows Bode plot of the frequency of the system OPLTF against the amplitude ratio and phase angle.

From bode plot we get the critical gain $K_{c}$ and critical period PU.

These are used to get the adjustable parameters $K_{\mathcal{o}} \tau_{i}$ and $\tau_{D}$ as shown in Table 2.

\section{Conclusion}

It is concluded that a tomato paste is processed successfully with specification satisfying the international standards. The procedure to process the tomato paste is simple including washing, sorting, pulping, juice extraction and evaporation. A control strategy was developed. The transfer functions were specified and the system is checked for stability and tuning. The control strategy includes the temperature to avoid oxidation, darkening of the color, and vitamin destruction. The composition and thickness of the paste are also controlled. 


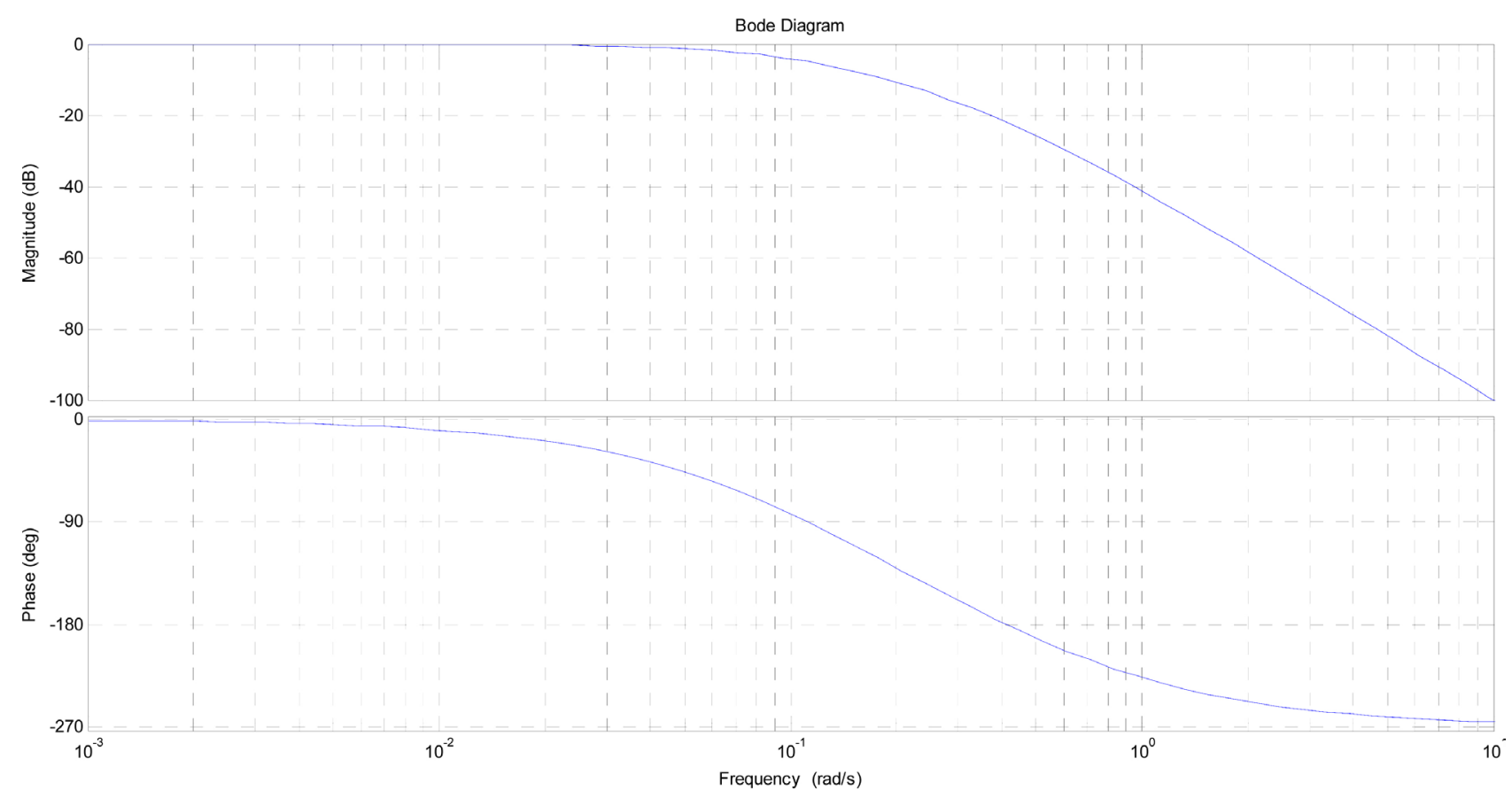

Figure 3. Bode plot.

Table 2. Bode plot and Z-N table data analysis.

\begin{tabular}{cccc}
\hline Type of controller & $K_{c}$ & $\tau_{I}, \operatorname{Sec}$ & $\tau_{D}, \operatorname{Sec}$ \\
\hline P & 6.275 & - & - \\
PI & 5.647 & 12.7 & - \\
PID & 7.53 & 7.62 & 1.9 \\
\hline
\end{tabular}

\section{Fund}

This research was funded by the Deanship of Scientific Research at Princess Nourah Bint Abdulrahman University through the Fast-track Research Funding Program.

\section{Conflicts of Interest}

The authors declare no conflicts of interest regarding the publication of this paper.

\section{References}

[1] Gadelrab, R.M.A. (2010) Managing Food Quality in Hotels: Integrated Quality Approaches to Food Production. Cardiff School of Management University of Wales Institute, Cardiff Llandaff Campus, Western Avenue Cardiff, Cardiff.

[2] Apaih, H.R.K. and Barringer, S.A. (2004) The Tomato Processing Including Information. 232.

[3] Thompson, A.K. (2018) Post Harrest Technology of Fruit and Vegetables. Blackwell Science, Oxford, 95.

[4] Wills, K. and Knack, V.B. (2010) Canning, Pickling, and Preserving. 88. 
[5] Atherton, J.G. and Rudich, J. (2004) Scientific Basics for Improvement: The Tomato Washing, Canning and Preservation of Tomato Paste.

[6] Grassineau, N.V. (2006) High-Precision EA-IRMS Analysis of S and C Isotopes in Geological Materials. Applied Geochemistry, 21, 756-765.

https://doi.org/10.1016/j.apgeochem.2006.02.015

[7] Suppiah, A. (2018) Food Safety Implementation in Hotels: Challenges and Benefits. http://www.sirim-qas.com.my/sirim/core-files/uploads/2018/02/Paper-2-by-Mr-An thony-Suppiah

[8] Morrison, P., Caffin, N. and Wallace, R. (2018) Small Food Service Establishments Still in Amber Light for Adopting Australian HACCP-Based Food Safety Code. British Food Journal, 100, 364-370. https://doi.org/10.1108/00070709810210285

[9] Sheppard, J., Kipps, M. and Thompson, J. (2015) Hygiene and Hazard in Food Service. In: Cooper, C.P. and Lockwood, A., Eds., Progress in Tourism, Recreation and Hospitality Management, Belhaven Press, London.

[10] Worsfold, D. (2016) Consumer Information on Hygiene Inspections of Food Premises. Journal of Foodservice, 17, 23-31. https://doi.org/10.1111/j.1745-4506.2006.00017.x

[11] Cooper, C.P. and Lockwood, A. (2002) Progress in Tourism, Recreation and Hospitality Management. Bellhaven Press, London, 192-226.

[12] Milwaukee, A. (2012) The Quality Auditor's HACCP Handbook. ASQ Food, Drug, and Cosmetic Division, ASQ Quality Press, Miami.

[13] Endorsed by BOD (2012) A Guide to the Preparation of a HACCP-Based Food Safety Management System for Hotels. Code of Practice No. (18)/2012 24 December.

[14] Kumar, A. (2009) HACCP in Hotel Industry-A Study on Its Application in Food Production. International Journal of Hospitality and Tourism Systems, 2, 162-180.

[15] Schlosser, E. (2005) Fast Food Nation: The Dark Side of the All American Meal. HarperCollins Publishers, New York.

[16] Mcginley, L.E. and Spurr, S. (2004) Honk for Service: A Man, a Tray and the Glory Days of the Drive-In Restaurant. Tray Days Publishing, Saint Louis.

[17] Schultz, H. and Yang, D.J. (1999) Pour Your Heart Into It: How Starbucks Built a Company One Cup at a Time. Hyperion.

[18] (1997) Hazard Analysis and Critical Control Point. HACCP. System and Guidelines for Its Application [Annex to CAC/RCP 1-1969, Rev. 3].

[19] HMSO (1990) Food Safety Act. HMSO, London.

[20] Stevenson, K.E. and Bernard, D.T. (1995) HACCP: Establishing Hazard Analysis Critical Control Point Programs. The Food Processors Institute, Washington DC.

[21] Zhang, M.W., Zhang, R.F. and Guo, B.J. (2006) The Hypolipidemic and Antioxidative Effects of Black Rice Pericarp Anthocyanin in Rats. Acta Nutrimenta Sinica, 28, 404-408.

[22] Li, N., Luo, M., Fu, Y., Zu, Y., Wang, W., Zhang, L., et al. (2013) Effect of Corilagin on Membrane Permeability of Escherichia coli, Staphylococcus aureus and Candida albicans. Phytotherapy Research, 27, 1517-1523. https://doi.org/10.1002/ptr.4891

[23] Deberdt, P., Perrin, B., Coranson-Beaudu, R., Duyck, P.-F. and Wicker, E. (2012) Effect of Allium fistulosum Extract on Ralstonia solanacearum Populations and Tomato Bacterial Wilt. Plant Disease, 96, 687-692.

https://doi.org/10.1094/PDIS-07-11-0601 
[24] Stevens, W.F. (1996) Chitosan: A Key Compound in Biology and Bioprocess Technology. In: Stevens, W.F., Rao, M.S. and Chandrkrachang, S., Eds., Proceedings of 2nd Asia Pacific Symposium, Bangkok, Thailand, 13-21.

[25] Alemu, D., Lemessa, F., Wakjira, M. and Berecha, G. (2013) Antibacterial Activity of Some Invasive Alien Species Extracts against Tomato (Lycopersicon esculentum Mill) Bacterial Wilt Caused by Ralstonia solanacearum (Smith). The Plant Pathology Journal, 12, 61-70. https://doi.org/10.3923/ppj.2013.61.70

[26] Ji, P., Momol, M.T., Olson, S.M., Pradhanang, P.M. and Jones, J.B. (2005) Evaluation of Thymol as Biofumigant for Control of Bacterial Wilt of Tomato under Field Conditions. Plant Disease, 89, 497-500. https://doi.org/10.1094/PD-89-0497

[27] Miyasaki, Y., Rabenstein, J.D., Rhea, J., Crouch, M.L., Mocek, U.M., Kittell, P.E., et al. (2013) Isolation and Characterization of Antimicrobial Compounds in Plant Extracts against Multidrug-Resistant Acinetobacter baumannii. PLoS ONE, 8, e61594. https://doi.org/10.1371/journal.pone.0061594

[28] Pradhanang, P.M., Momol, M.T., Olson, S.M. and Jones, J.B. (2003) Effects of Plant Essential Oils on Ralstonia solanacearum Population Density and Bacterial Wilt Incidence in Tomato. Plant Disease, 87, 423-427.

https://doi.org/10.1094/PDIS.2003.87.4.423

\section{Websites}

[01] https://www.dur.sa/ar/news-and-media/blog/ 